\title{
Selected Water Physico-Chemical Characteristics of Iloilo Batiano River, Philippines: A Baseline Study
}

\author{
Bartimeues Nathan Wiederhold, Tom Lichtenberg, Roderick R. Germo, and Brian Gil S. Sarinas
}

\begin{abstract}
Protecting our natural resources is one of the important thrusts of every organization. In this study, the waters of Iloilo Batiano River, Philippines is explored. This study was conducted because there is a dearth of information on the water physico-chemical characteristics of the river. Since this is an initial assessment, this study will serve as a baseline data and the results will serve as a basis for future reference for conservation measures of the river. The present study aimed to determine the selected water physico-chemical characteristics of the river such as the electrical conductivity (EC), temperature, $\mathrm{pH}$, and calcium content; assess if these parameters exceed the limit set by the DENR Administrative Order No. 20F16-08 of the Republic of the Philippines and other available literatures; and to determine if there was no significant difference in the water physico-chemical characteristics among the six sampling stations. Results revealed that $\mathrm{EC}$ and calcium content of the river exceed their limits except for temperature and pH levels. Furthermore, EC and temperature were statistically different among the six sampling stations except for $\mathbf{p H}$ values. This study concludes that the river is saline due to the mixing of saltwater and surface water as the river is near to the sea and has high calcium content that can threaten the life of freshwater aquatic organisms.
\end{abstract}

Index Terms-Electrical conductivity (EC), temperature, $\mathrm{pH}$, calcium content, Iloilo.

\section{INTRODUCTION}

Rivers serve as livelihood source, water source, agricultural lifeblood and key to economic prosperity. Much of our ancient civilizations thrive near river banks. Rivers also carry nutrients from high lying mountains down to the lowland plains. Nitrogen $(\mathrm{N})$ and Phosphorus $(\mathrm{P})$ are some of the nutrients that rivers transport especially during monsoon seasons [1]. Along with the thriving benefits ultimately, rivers promote urbanization. However, urbanizations that lack planning brings negative impact to the environment [2]. In addition, natural disasters and climate change also bring about changes on the river environments [3].

The present study focused on Batiano River, Iloilo, Philippines. This river is a waterway of approximately 9.8 $\mathrm{km}(6.1 \mathrm{mi})$ in length originating from Brgy. Santa Clara,

Manuscript received January 12, 2021; revised May 24, 2021.

B. N. Wiederhold and T. Lichtenberg are with Van Hall Larenstein, University of Applied Sciences, Netherlands (e-mail: bart.wiederhold@gmail.com, Tom.lichtenberg@hvhl.nl).

R. Germo and B. G. Sarinas are with John B. Lacson Foundation Maritime University (Arevalo), Inc. at Sto. Niño Sur, Arevalo, Iloilo city, Philippines (e-mail: roderick.germo@jblfmu.edu.ph, briangil.sarinas@jblfmu.edu.ph).
Oton, Iloilo $\left(10^{\circ} 41^{\prime} \mathrm{N}, 122^{\circ} 28^{\prime} \mathrm{E}\right)$ approximately $10 \mathrm{~km}(6.1$ mi) from Iloilo City to Brgy. Villa Alegre, Molo, Iloilo City $\left(10^{\circ} 41^{\prime} \mathrm{N}, 122^{\circ} 33^{\prime} \mathrm{E}\right)$ and empties into the Iloilo Strait [4]. The river originates on agricultural fields adjoining the Iloilo River on the north of Oton, Iloilo passing down to Arevalo and Molo, Iloilo City [5] where mostly residential and commercial areas are situated. Since water is a vital source of life, the underlying aquatic sediments also pose the same importance [6]. A group of researchers [7] assessed the Iloilo Batiano River's sediments for heavy metal assessment and found out that the river was contaminated with heavy metals such as chromium and lead and exceed the Philippine standard values. Similarly, the Iloilo River was found out to have similar heavy metals with varying conditions. To add to, according to the study about $50 \%$ of the heavy metals found may be released to the water column infecting aquatic organisms in effect [8].

Furthermore, the Ambient Water Quality Report of Batiano River for 2015 revealed that the river is a recipient of many pollutants. Present estuarine of Iloilo is a subject of great pollution which deteriorates the quality of the river due to urbanization. Major pollution sources include commercial establishments, institutions, informal settlers, sewage, animal wastes, transportation, crude oil residues and human refuses [9]. In addition, the Station 7 (Sta. Cruz Bridge, Molo, Iloilo City, Philippines) exceeded in BOD value. Coliform concentration is also high exceeding the standard value bringing the river non-compliant to water quality standard criteria for Class " $C$ " water [5]. To bring remedy to this, several conservation plans have been drawn out by the provincial government with the Integrated River Basin Management and Development Master Plan for Iloilo-Batiano River Basin [10] as the highlight mainly to improve river water quality [11] through different projects mainly based on ecological river engineering [12] for supporting the river's sustainability. This project was materialized under the office of the River Basin Control Office (RBCO) by virtue of Executive Order 510 [13].

The physico-chemical characteristics such as electrical conductivity and $\mathrm{pH}$ levels denote water quality [14].

With regards to physico-chemical properties of waters, Itaogbolu area in Nigeria was found to have $\mathrm{pH}(6.59-7.68)$, temperature $\left(21.10{ }^{\circ} \mathrm{C}-27.10{ }^{\circ} \mathrm{C}\right)$, and electrical conductivity $(300 \mu \Omega / \mathrm{cm}-1150 \mu \Omega / \mathrm{cm})$ [15]. Similarly, Kollegal stretch of River Cauvery in India rages its physico-chemical properties as $\mathrm{pH}(7.46-8.31)$, temperature $\left(22.9{ }^{\circ} \mathrm{C}-30.5{ }^{\circ} \mathrm{C}\right)$, electrical conductivity $(261.3 \mu \mathrm{S} / \mathrm{cm}-$ $419.9 \mu \mathrm{S} / \mathrm{cm})$, and calcium $(60.94 \mathrm{mg} / \mathrm{L}-105.8 \mathrm{mg} / \mathrm{L})$. According to the Bureau of Indian Standards (BIS) and National River quality standards, the river is not essentially polluted and falls within permissible limits [14]. 
Meanwhile, on River Kapila in India, the waters were found out to have the following: $\mathrm{pH}(6.7-7.35)$, temperature $\left(24^{\circ} \mathrm{C}-27^{\circ} \mathrm{C}\right)$, and calcium $(7.80 \mathrm{mg} / \mathrm{L}-24.48 \mathrm{mg} / \mathrm{L})$ [16]. In contrast, untouched water systems that are free from human disturbance like Manipur River in India showed permissible parameters where $\mathrm{pH}(6.8-7.9)$, calcium $(6.01$ $\mathrm{mg} / \mathrm{L}-8.52 \mathrm{mg} / \mathrm{L})$, temperature $\left(16.0^{\circ} \mathrm{C}-26.0{ }^{\circ} \mathrm{C}\right)$, and electrical conductivity $(124.0 \mu \mathrm{S} / \mathrm{cm}-460 \mu \mathrm{S} / \mathrm{cm})[17]$.

The identification and classification of water quality of Salak River in Malaysia based on physico-chemical characteristics found out that $\mathrm{pH}(6.98-7.52)$, electrical conductivity $(36000 \mu \mathrm{S} / \mathrm{cm}-41000 \mu \mathrm{S} / \mathrm{cm})$, and temperature $\left(28.1^{\circ} \mathrm{C}-28.7^{\circ} \mathrm{C}\right)$ levels fall under Class V of Malaysian waters [18].

On the other hand, the physico-chemical analysis of Buhisan River in Cebu, Philippines was also conducted and revealed that temperature $\left(27.52^{\circ} \mathrm{C}-28.87^{\circ} \mathrm{C}\right)$ and $\mathrm{pH}(7.17$ - 7.60) were under normal parameters [19]. In addition, the Mananga River also in Cebu, Philippines was also analyzed. Only pH $(8.03-8.76)$ was found to be higher than Buhisan River [20]. Meanwhile, the Mamba River of Southern Luzon, Philippines was also tested for water assessment such as $\mathrm{pH}$ (8.1) and temperature $\left(26.9^{\circ} \mathrm{C}\right)$ and based on the given standards of the DENR, the waters are non-polluted and suitable for development and agricultural use [21]. Furthermore, in the Carangan Estero, Ozamiz City, Philippines, the results denote a deteriorating water quality mainly due to commercial and residential refuses attributed to dense population and thriving commerce [22].

Human activity has by far the greatest reason of water pollution. Truth is that not only rivers are polluted but also waterways and reservoirs. Manair Reservoir at India was tested and it was found out that physico-chemical characteristics are within permissible limits of the standards and hence, can be used for consumption [23]. Effluents, as a human by product of South Africa, water effluents were tested and all exceeded the levels of South African Guidelines and World Health Organization's [24] tolerance limits [25].

Thus, this study was conceptualized because of the following reasons: First, there is a dearth of information on the water physico-chemical characteristics in Iloilo Batiano River. Second, since this is an initial assessment, this study will serve as a baseline data. Third, the results will serve as a basis for future reference, and finally, for conservation measures of Iloilo Batiano River.

The present study aimed to determine the selected water physico-chemical characteristics of the Batiano River in Iloilo, Philippines such as electrical conductivity (EC), temperature, $\mathrm{pH}$, and calcium content; identify if the selected water physico-chemical characteristics meet the standard values; and to evaluate if there are significant differences in the selected water physico-chemical characteristics among the six sampling stations.

This study is only limited to selected water physico-chemical characteristics such as electrical conductivity (EC), temperature, $\mathrm{pH}$, and calcium content. Other parameters were not measured due to resource limitations.

\section{MAterials AND Methods}

\section{A. Research Design}

This research used survey as a research design to determine the values of the selected water physico-chemical characteristics such as electrical conductivity $(\mu \mathrm{S} / \mathrm{cm})$, temperature $\left({ }^{\circ} \mathrm{C}\right), \mathrm{pH}$, and calcium content $(\mathrm{mg} / \mathrm{L})$ among the six sampling stations of Iloilo Batiano River for the month of November 2018.

\section{B. Materials}

The materials used were the electrical conductivity measurement device (WTW Cond 3110), also capable of measuring the temperature; $\mathrm{pH}$ (1-14) measuring paper; and calcium testing kit (Manual MColortest - Calcium Test / HC548200 / 1.11110.0001).

\section{Location of the Sampling Stations}

There were six sampling stations (see Figure 1) located at Poblacion North at Oton, Iloilo Province (Station 1), Alegre in Oton, Iloilo Province (Station 2), Sto. Nino Sur at Arevalo, Iloilo City (Station 3), Yulo Drive at Arevalo, Iloilo City (Station 4), Calumpang, Iloilo City (Station 5), and Molo Boulevard at Molo, Iloilo City (Station 6). Figure 2 shows the sample photographic views.

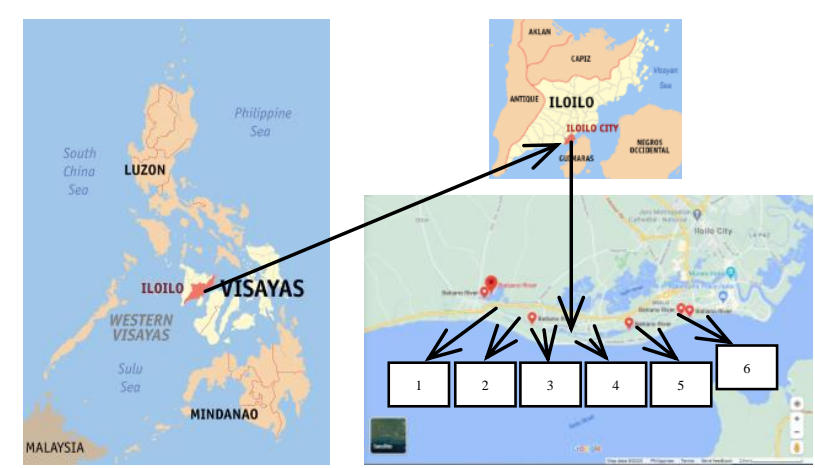

Fig. 1. Location of six sampling stations (credit to Wikipedia for the Philippine and Western Visayas maps while Iloilo Batiano River to Google Map).
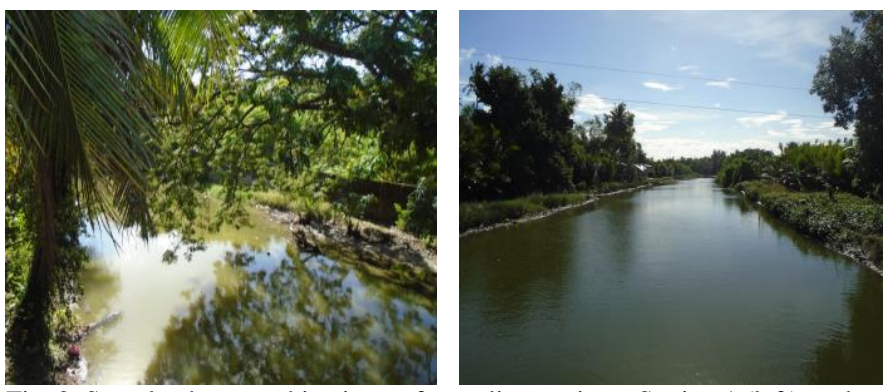

Fig. 2. Sample photographic views of sampling stations: Station 1 (left) and Station 2 (right).

\section{Data Collection}

Every location consisted of three measurements: one on the right, one in the middle, and at last one at the left. Every sample measuring starts with testing the salinity. After the salinity measurement, the $\mathrm{pH}$ was determined. This makes use of a $\mathrm{pH}$ paper, with yellow plain color. Then it was compared with the color table, where every color has a number from $1-14$. Finally, the calcium content was measured. This was done by a MColortest Calcium testing kit. 
The testing kit contains potassium hydroxide. After following some steps by using the method titrimetric with titration pipette, the amount of calcium (in $\mathrm{mg} / \mathrm{L}$ ) in a water sample was determined. Note that the chloride testing kit has not been used. Since the salinity was extremely high in the river, it was not possible to determine the chloride current, since an extreme amount of measuring liquid is then needed.

\section{E. Data Analysis}

One-way Analysis of Variance (ANOVA) set at .05 level of significance was used to test if there were no significant differences in the selected water physico-chemical characteristics such as electrical conductivity, temperature, and $\mathrm{pH}$ among the six sampling stations of Iloilo Batiano River. In addition, Scheffe test was used to compare the means of the selected water physico-chemical characteristics among the six sampling stations.

The Philippine values [26] was used as a basis to compare if the selected water physico-chemical characteristics exceed or still at the normal values. Table I shows the values of electrical conductivity (EC), and its application [27]. The amount of calcium in freshwater range from $75 \mathrm{mg} / \mathrm{L}$ [28].

TABLE I: VALUES OF ELECTRICAL CONDUCTIVITY (EC) AND ITS CORRESPONDING APPLICATIONS

\begin{tabular}{|l|l|}
\hline Conductivity & \multicolumn{1}{c|}{ Application } \\
\hline $1 \mu \mathrm{S} / \mathrm{cm}$ & Laboratory \\
\hline $5 \mu \mathrm{S} / \mathrm{cm}$ & Irons, batteries \\
\hline $30 \mu \mathrm{S} / \mathrm{cm}$ & Excellent drinking water \\
\hline $600-800 \mu \mathrm{S} / \mathrm{cm}$ & Most common tap water \\
\hline $50,000 \mu \mathrm{S} / \mathrm{cm}$ & Seawater \\
\hline
\end{tabular}

\section{RESUlTS AND DISCUSSION}

\section{A. Water Physico-Chemical Characteristics in Station 1}

In Station 1, the average EC is $13856.7 \mu \mathrm{S} / \mathrm{cm}$ which exceeds 600-800 $\mu \mathrm{S} / \mathrm{cm}$, thus, considered saline [27] and not fit for propagation and growth of freshwater fish, agriculture, irrigation, and livestock watering [26].

The average temperature is $28.1^{\circ} \mathrm{C}$ which is within the limit [26]. Malaysian Salak River has also the same temperature range by $28.1^{\circ} \mathrm{C}-28.7^{\circ} \mathrm{C}$ [18].

The $\mathrm{pH}$ of the river at Station 1 is also within the limit (7.1) which is between 6.5 and 9.0 [26]. Moreover, the Buhisan River exceeds this $\mathrm{pH}$ by around $6 \%$ ranging from 7.17 to 7.60 [19]. Meanwhile, the calcium content is $192 \mathrm{mg} / \mathrm{L}$ which is very high that might affect the freshwater organisms [28].

TABLE II: WATER PHYSICO-CHEMICAL CHARACTERISTICS OF STATION 1

\begin{tabular}{ccccccc}
\hline \hline Location & Latitude & Longitude & $\begin{array}{c}\mathrm{EC} \\
(\mu \mathrm{S} / \mathrm{cm})\end{array}$ & $\begin{array}{c}\text { Temp } \\
\left({ }^{\circ} \mathrm{C}\right)\end{array}$ & $\mathrm{pH}$ & $\begin{array}{c}\text { Calcium } \\
(\mathrm{mg} / \mathrm{L})\end{array}$ \\
\hline Right & $106,934,328,430$ & $1,224,801,516,150$ & 13660 & 28.0 & 7.2 & \\
Middle & $106,934,459,310$ & $1,224,801,556,740$ & 13960 & 28.2 & 7.1 & 192 \\
Left & $106,933,929,330$ & $1,224,801,463,530$ & 13950 & 28.1 & 7.0 & \\
& & Grand Mean & $\mathbf{1 3 8 5 6 . 7}$ & $\mathbf{2 8 . 1}$ & $\mathbf{7 . 1}$ & \\
\hline \hline
\end{tabular}

\section{B. Water Physico-Chemical Characteristics in Station 2}

The average EC of Station 2 is $16423.3 \mu \mathrm{S} / \mathrm{cm}$ which exceeds 600-800 $\mu \mathrm{S} / \mathrm{cm}$, thus, considered saline [27] and not fit for propagation and growth of fish, agriculture, irrigation, and livestock watering [26]. This exceeds Manupur River's conductance in India [17] by around 36 times.
The average temperature is $29^{\circ} \mathrm{C}$ which is within the limit [26]. The results complemented the findings for Kollegal River stretch in India [14].

The $\mathrm{pH}$ of the river at Station 2 is also within the limit (7.0) which is between 6.5 and 9.0 [26]. The results also complement with the findings in the Nigerian Itaogbolu waters [15].

On the other hand, the calcium content is $133 \mathrm{mg} / \mathrm{L}$ which is very high (despite its being the lowest of all stations). A very high calcium content might be critical to freshwater organisms [28]. The river's calcium content exceeded India's Kapila River [16] by more than 5 times.

\begin{tabular}{ccccccc}
\multicolumn{6}{c}{ TABLE III: WATER PHYSICO-CHEMICAL CHARACTERISTICS OF STATION 2 } \\
\hline \hline Location & Latitude & Longitude & $\begin{array}{c}\text { EC } \\
(\mu \mathrm{S} / \mathrm{cm})\end{array}$ & $\begin{array}{c}\text { Temp } \\
\left({ }^{\circ} \mathrm{C}\right)\end{array}$ & $\mathrm{pH}$ & $\begin{array}{c}\text { Calcium } \\
(\mathrm{mg} / \mathrm{L})\end{array}$ \\
\hline Right & $106,877,564,310$ & $1,224,938,560,160$ & 16750 & 29.2 & 6.9 & \\
Middle & $106,877,914,290$ & $1,224,938,734,430$ & 16330 & 28.9 & 7.0 & 133 \\
Left & $106,877,025,380$ & $1,224,937,878,280$ & 16190 & 29.0 & 7.2 & 130 \\
& & Grand Mean & $\mathbf{1 6 4 2 3 . 3}$ & $\mathbf{2 9 . 0}$ & $\mathbf{7 . 0}$ & \\
\hline \hline
\end{tabular}

\section{Water Physico-Chemical Characteristics in Station 3}

In Station 3, the average EC is $19563.3 \mu \mathrm{S} / \mathrm{cm}$ which exceeds 600-800 $\mu \mathrm{S} / \mathrm{cm}$, thus, considered saline [27] and not fit for propagation and growth of freshwater fish, agriculture, irrigation, and livestock watering [26]. Meanwhile, the Kollegal River shows less conductance [14].

The average temperature is $28.9^{\circ} \mathrm{C}$ which is within the limit [26]. The temperature is close to the Salak River in Malaysia [18].

The $\mathrm{pH}$ of the river at Station 3 is in good condition (7.1) which is between 6.5 and 9.0 [26]. In comparison to Mananga and Buhisan Rivers [20], the $\mathrm{pH}$ result was much lower compared to the aforementioned rivers.

Moreover, the calcium content is very high $(186 \mathrm{mg} / \mathrm{L})$. This is more than twice the limit where the situation might threaten the life of aquatic organisms [28]. It is around 28 times the calcium current of Manipur River in India [17].

\begin{tabular}{ccccccc}
\multicolumn{6}{c}{ TABLE IV: WATER PHYSICO-CHEMICAL CHARACTERISTICS OF STATION 3 } \\
\hline \hline Location & Latitude & Longitude & $\begin{array}{c}\text { EC } \\
(\mu \mathrm{S} / \mathrm{cm})\end{array}$ & $\begin{array}{c}\text { Temp } \\
\left({ }^{\circ} \mathrm{C}\right)\end{array}$ & $\mathrm{pH}$ & $\begin{array}{c}\text { Calcium } \\
(\mathrm{mg} / \mathrm{L})\end{array}$ \\
\hline Right & $106,847,912,660$ & $1,225,005,269,290$ & 19810 & 28.8 & 7.0 & \\
Middle & $106,847,961,060$ & $1,225,004,704,610$ & 19360 & 28.9 & 7.3 & 186 \\
Left & $106,848,115,310$ & $1,225,005,219,570$ & 19520 & 29.0 & 7.1 & \\
& & Grand Mean & $\mathbf{1 9 5 6 3 . 3}$ & $\mathbf{2 8 . 9}$ & $\mathbf{7 . 1}$ & \\
& & &
\end{tabular}

\section{Water Physico-Chemical Characteristics in Station 4}

Stations 1 to 3 were measured between 8 AM to 9 AM while Stations 4 to 6 were measured between 4 PM to 6 PM. Station 3 was measured when the high tide was coming in, where Station 4 was measured when the low tide was coming in. Since Station 4 is the closest to the Iloilo Strait, it is very tide-sensitive.

The EC is $18416.7 \mu \mathrm{S} / \mathrm{cm}$ which exceeds $600-800 \mu \mathrm{S} / \mathrm{cm}$, thus, considered saline [27] and not fit for propagation and growth of freshwater fish, agriculture, irrigation, and livestock watering [26].

The average temperature is $31.9^{\circ} \mathrm{C}$ which exceeds the limit [26] that maybe due to the time of sampling however, a minimal increase. The temperature readings are closely similar [5] for the river monitoring. 
The $\mathrm{pH}$ of the river at Station 4 is in good condition (7.2) which is between 6.5 and 9.0 [26].

Furthermore, the calcium content is very high $(191 \mathrm{mg} / \mathrm{L})$ that might be critical to the growth of biotic ecosystem [28]. As compared to that of Kapila River [16], the calcium content exceeds by around 7.8 times. greatly lower than Buhisan River [20].

The calcium content on the other hand is very high (198 $\mathrm{mg} / \mathrm{L}$ ) that can be fatal to the growth of freshwater organisms [28]. The calcium content is around 7 times higher than that of Kapila River [16] and about $87 \%$ higher than that of Kollegal River [14].

TABLE V: WATER PHYSICO-CHEMICAL CHARACTERISTICS OF STATION 4

TABLE VII: WATER PHYSICO-CHEMICAL CHARACTERISTICS OF STATION 6

\begin{tabular}{|c|c|c|c|c|c|c|c|c|c|c|c|c|c|}
\hline Location & Latitude & Longitude & $\begin{array}{c}\text { EC } \\
(\mu \mathrm{S} / \mathrm{cm})\end{array}$ & $\begin{array}{l}\text { Temp } \\
\left({ }^{\circ} \mathrm{C}\right)\end{array}$ & $\overline{\mathrm{pH}}$ & $\begin{array}{c}\text { Calcium } \\
(\mathrm{mg} / \mathrm{L})\end{array}$ & Location & "Latitude & Longitude & $\begin{array}{c}\text { EC } \\
(\mu \mathrm{S} / \mathrm{cm})\end{array}$ & $\begin{array}{l}\text { Temp } \\
\left({ }^{\circ} \mathrm{C}\right)\end{array}$ & $\overline{\mathrm{pH}}$ & $\begin{array}{c}\text { Calcium } \\
(\mathrm{mg} / \mathrm{L})\end{array}$ \\
\hline Right & $106,810,868,690$ & $1,225,173,432,520$ & 18480 & 32.1 & 7.4 & \multirow{3}{*}{191} & Right & $106,908,955,000$ & $1,225,491,223,870$ & 40700 & 29.4 & 7.2 & \multirow{3}{*}{198} \\
\hline Middle & $106,811,103,680$ & $1,225,173,432,520$ & 18650 & 32.1 & 7.2 & & Middle & $106,907,862,940$ & $1,225,492,852,250$ & 41200 & 29.2 & 7.0 & \\
\hline \multirow[t]{2}{*}{ Left } & $106,810,905,760$ & $1,225,173,618,500$ & 18120 & 31.4 & 7.1 & & Left & $106,909,516,450$ & $1,225,491,820,810$ & 37300 & 29.2 & 7.1 & \\
\hline & & Grand Mean & 18416.7 & 31.9 & 7.2 & & & & Grand Mean & 39733.3 & 29.3 & 7.1 & \\
\hline
\end{tabular}

\section{E. Water Physico-Chemical Characteristics in Station 5}

Salinity is the second highest in Station 5. The EC is 34700 $\mu \mathrm{S} / \mathrm{cm}$ which exceeds $600-800 \mu \mathrm{S} / \mathrm{cm}$, thus, considered saline [27] and not fit for propagation and growth of freshwater fish, agriculture, irrigation, and livestock watering [26]. The numbers exceeds Kollegal River [14] and Manipur River [17]. Since Station 5 is near the Iloilo Strait, high values may be attributed to the brackish nature of the water. Regardless of the tide, salt and other minerals attributed to seawater are deposited in its bed giving overwhelming readings of electric conductance.

The average temperature is $30.2^{\circ} \mathrm{C}$ which is within the limit [26]. Contrasting temperatures of waters is attributed to heat convection. In comparison, Buhisan River [19] is much lower on temperature with Batiano River.

The $\mathrm{pH}$ of the river at Station 5 is in good condition (6.9) which is between 6.5 and 9.0 [26]. The $\mathrm{pH}$ reading is closely comparable to the Indian Maniar Reservoir [23].

Meanwhile, the calcium content is very high $(174 \mathrm{mg} / \mathrm{L})$ that can be fatal to the like of freshwater organism [28]. Calcium is around $64 \%$ higher compared to Kollegal River [14] and about 6 times higher than Kapila River [16].

TABLE VI: WATER PHYSICO-CHEMICAL CHARACTERISTICS OF STATION 5

\begin{tabular}{ccccccc}
\hline \hline Location & Latitude & Longitude & $\begin{array}{c}\mathrm{EC} \\
(\mu \mathrm{S} / \mathrm{cm})\end{array}$ & $\begin{array}{c}\text { Temp } \\
\left({ }^{\circ} \mathrm{C}\right)\end{array}$ & $\mathrm{pH}$ & $\begin{array}{c}\text { Calcium } \\
(\mathrm{mg} / \mathrm{L})\end{array}$ \\
\hline Right & $106,877,626,130$ & $1,225,389,038,180$ & 35300 & 30.1 & 6.9 & \\
Middle & $106,877,520,950$ & $1,225,388,432,850$ & 33600 & 30.3 & 7.0 & 174 \\
Left & $106,879,840,320$ & $1,225,387,663,320$ & 35200 & 30.3 & 6.8 & \\
& & Grand Mean & $\mathbf{3 4 7 0 0}$ & $\mathbf{3 0 . 2}$ & $\mathbf{6 . 9}$ & \\
& & &
\end{tabular}

\section{F. Water Physico-Chemical Characteristics in Station 6}

Station 6 is the station which is located the nearest to the Iloilo Strait. The average salinity is extremely high (39733.3 $\mu \mathrm{S} / \mathrm{cm}$ ) but not unexpected (because the location is near the Iloilo Strait). The current is very close to the salinity of seawater (around $50000 \mu \mathrm{S} / \mathrm{cm}$ ) thus, considered saline [27] and not fit for propagation and growth of freshwater fish, agriculture, irrigation, and livestock watering [26]. This is closely comparable to the Salak River in Malaysia with conductivity range of 36000 to $41000 \mu \mathrm{S} / \mathrm{cm}$ [18].

The average temperature is $29.3{ }^{\circ} \mathrm{C}$ which is within the limit [26]. This is close to the readings made on Salak River [18] and Buhisan River [19].

The $\mathrm{pH}$ of the river at Station 6 is in good condition (7.1) which is between 6.5 and 9.0 [26]. The $\mathrm{pH}$ is close to the results of the water testing on Manair Reservoir [23] and is
Table VIII shows that there are significant differences in terms of EC, $F(5,12)=364.864, p=.000$ and temperature, $F$ $(5,12)=134.297, p=.000$ among the six sampling stations. This means that one of the sampling stations is different from each other.

Meanwhile, no significant difference was observed in $\mathrm{pH}$, $F(5,12)=2.220, p=.120$ among the six sampling stations. This implies that $\mathrm{pH}$ values are the same regardless of the station. Calcium was excluded in the One-ANOVA computation due to similarity of values in the respective station.

TABLE VIII: ONE-WAY ANOVA RESULTS FOR THE SIGNIFICANT DIFFERENCES IN THE EC, TEMPERATURE, AND PH VALUES

\begin{tabular}{llccccc}
\hline \hline \multirow{2}{*}{ Test } & \multirow{2}{*}{ Sources of Variation } & SS & df & MS & F & Sig. \\
\hline \multirow{2}{*}{ EC } & Between Groups & 1.719 & 5 & 3.437 & $364.864 *$ & .000 \\
& Within Groups & 1.131 & 12 & 942094.444 & & \\
& Total & 1.730 & 17 & & & \\
& Between Groups & 26.113 & 5 & 5.223 & $134.297 *$ & .000 \\
\multirow{2}{*}{$\mathrm{C}$} & Within Groups & .467 & 12 & .039 & & \\
& Total & 26.580 & 17 & & & \\
& Between Groups & .185 & 5 & .037 & 2.220 & .120 \\
$\mathrm{pH}$ & Within Groups & .200 & 12 & .017 & & \\
& Total & .385 & 17 & & & \\
\hline \hline
\end{tabular}

Note. Asterisk (*) means significant at .05 level of probability.

Furthermore, Stations 5 and 6 are both significantly different from the rest of the sampling stations. However, Station 6 has the highest value in EC and at the same time, significantly different from the other sampling stations. This might be attributed to the nearness of the river to the sea. Nevertheless, the results greatly support that commercial and residential refuses deteriorates the water quality in conjunction with the rapid increase of population and the boom of commerce [22]. This study also supports that pollution sources which are present along the stretch of the river [9]. To add, the presence of heavy metals on the sediment bed of the river also gives more meaning to the results [7]. In effect, the release of heavy metals on water column will highly destroy the river's ecosystem since the Philippine is closely approaching the typhoon season [8].

TABLE IX: COMPARISON OF MEANS IN EC AMONG STATIONS

\begin{tabular}{cc}
\hline \hline Station & Mean \\
\hline 1 & $13,856.7^{\mathrm{a}}$ \\
2 & $16,423.3^{\mathrm{ab}}$ \\
3 & $19,563.3^{\mathrm{c}}$ \\
4 & $18,416.7^{\mathrm{bc}}$ \\
5 & $34,700^{\mathrm{d}}$ \\
6 & $39,733.3^{\mathrm{e}}$ \\
\hline \hline
\end{tabular}


Moreover, Stations 1, 4, and 5 are significantly different from the rest of the sampling stations as shown in Table X. However, Station 1 has the lowest values in temperature while Station 4 has the highest temperature of them all and is statistically different from other stations. This might be attributed to the varied chemicals dumped in the river.

\begin{tabular}{cc} 
TABLE X: COMPARISON OF MEANS IN TEMPERATURE AMONG STATIONS \\
\hline \hline Station & Mean \\
\hline 1 & $28.10^{\mathrm{a}}$ \\
2 & $29.0^{\mathrm{b}}$ \\
3 & $28.90^{\mathrm{b}}$ \\
4 & $31.9^{\mathrm{d}}$ \\
5 & $30.2^{\mathrm{c}}$ \\
6 & $29.3^{\mathrm{b}}$ \\
\hline \hline
\end{tabular}

\section{CONCLUSIONS}

Based on the foregoing results, this study concludes that Batiano River is saline because the river is near to the sea and has high calcium content that might threaten the life of freshwater aquatic organisms. This may be attributed to irresponsible management of wastes being thrown in the river.

The city government of Iloilo must focus its attention in saving Batiano River. A water filter and litter trap can be placed in the middle of Stations 1 and 2, then at the middle of Stations 5 and 6, and finally, at the end point of Station 6 to filter wastes and litter before these get further downstream or even flow into the Iloilo Strait. Furthermore, different stakeholders such as the Local Government Units (LGU's), private sectors, and residents should strategize to conserve Batiano River as a legacy to the next generation.

\section{CONFLICT OF INTEREST}

The authors declare no conflict of interest.

\section{AUTHOR CONTRIBUTIONS}

B. N. Wiederhold and T. Lichtenberg collected water samples, measured its physico-chemical parameters, and contributed inputs to the manuscript; R. Germo analyzed the data and contributed inputs to the manuscript especially for related literatures; and B. G. Sarinas wrote and edited the final manuscript. All authors had approved the final version.

\section{REFERENCES}

[1] J. E. Hilario and T. R. Perez, "Predicting transport of nutrients from three tributary rivers of Taal Lake, Philippines," Philippine Agricultural Scientist, vol. 96, pp. 187-197, 2013.

[2] C. Wang, D. Wang, H. Wang, and R. Dong, "Impacts of urbanisation on river systems and their functions in Yanggong river watershed of Lijiang city," International Journal of Sustainable Development and World Ecology, vol. 18, no. 6, pp. 498-502, 2011.

[3] S. J. Ormerod, "Climate change, river conservation and the adaptation challenge," Aquatic Conservation: Marine and Freshwater Ecosystems, vol. 19, pp. 609-613, 2009.

[4] Google Earth. (2018). [Online]. Available: https://www.google.com.ph/ maps/@10.6818086,122.5192998,13.92z

[5] Environmental Management Bureau Region VI. (2015). Ambient Water Quality Report. [Online]. Available: http://r6.emb.gov.ph/wpcontent/uploads/2016/05/AWQAR-Annual-2 015.docx
[6] A. Mudroch. (2017). Manual of Physico-Chemical Analysis of Aquatic Sediments. [Online]. Available: https://www.taylorfrancis.com/books/e/97813 51433822

[7] B. G. S. Sarinas, L. D. Gellada, E. B. Jamolangue, and M. R. Teruñez, "Assessment of heavy metals in sediments of Iloilo Batiano river, Philippines," International Journal of Environmental Science and Development, vol. 5, no. 6, pp. 543-546, 2014.

[8] H. S. Taberna, M. G. G. Nillos, I. G. Pahila, and J. P. B. Arban, "Distribution and geochemical behaviour of heavy metals $(\mathrm{Cr}, \mathrm{Cu}, \mathrm{Ni}$ and $\mathrm{Pb}$ ) in Iloilo river estuarine sediments," Advances in Environmental Sciences, vol. 7, no. 1, pp. 11-19, 2015.

[9] P. Taneza and R. P. Philp, "A preliminary study of the sources of organic pollutants in the Iloilo River, Philippines," Environmental Forensics, vol. 10, no. 1, pp. 68-81, 2009.

[10] DENR River Basin Control Office. (2014). Formulation of an Integrated River Basin Management and Development Master Plan for Iloilo-Batiano River Basin. [Online]. Available: http://rbco.denr.gov.ph/wp-contents/uploads/2017/10/IloiloBatianoex ecutevesummary.pdf

[11] M. Somo. (2014). City Accepts 10-Year Action Plan on River Water Quality. [Online]. Available: http://www.iloilo.net.ph/city-accepts-10-year-action-plan-river-waterquality/

[12] H. Woo, "Trends in ecological river engineering in Korea," Journal of Hydro-environment Research, vol. 4, no. 4, pp. 269-278, 2010.

[13] DENR Region VI. (2013). Master Plan for the Iloilo-Batiano River Basin to Address Flooding and Sustainable Water Supply Now Underway. [Online]. Available: http://r6.denr.gov.ph/index.php/86-region-news-items/274-master-pla $\mathrm{n}$-for-the-iloilo-batiano-river-basin-to-address-flooding-and-sustainab le-water-supply-now-underway

[14] K. Venkatesharaju, P. Ravikumar, R. K. Somashekar, and K. L. Prakash, "Physico-chemical and bacteriological investigation on the river Cauvery of Kollegal stretch in Karnataka," Kathmandu University Journal of Science, Engineering and Technology, vol. 6, no. 1, pp. $50-59,2010$

[15] S. O. Adefemi and E. E. Awokunmi, "Determination of physico-chemical parameters and heavy metals in water samples from Itaogbolu area of Ondo-State, Nigeria," African Journal of Environmental Science and Technology, vol. 4, no. 3, pp. 145-148, 2010.

[16] A. D. Smitha and P. Shivashankar, "Physico chemical analysis of the freshwater at river Kapila, Nanjangudu industrial area, Mysore, India," International Research Journal of Environment Sciences, vol. 2, no. 8, pp. 59-65, 2013.

[17] M. R. Singh, A. Gupta, and K. H. Beeteswari, "Physico-chemical properties of water samples from Manipur River system, India," Journal of Applied Sciences and Environmental Management, vol. 14, no. 4 , pp. $85-89,2010$.

[18] N. A. Rosli, M. H. Zawawi, and R. A. Bustami, "Salak river water quality identification and classification according to physico-chemical characteristics," Procedia Engineering, vol. 50, pp. 69-77, 2012.

[19] F. Maglangit, R. Galapate, and E. Bensig, "Physico-chemical assessment of the water quality of Buhisan River, Cebu, Philippines," International Journal of Research in Environmental Science and Technology, vol. 4, pp. 83-87, 2014.

[20] M. J. Flores and M. T. Zafaralla, "An assessment of the physicochemical parameters of Mananga River, Cebu, Philippines," IAMURE International Journal of Ecology and Conservation, vol. 4, no. 1, pp. 34-61, 2012.

[21] F. B. Martinez, M. B. B. Mijares, and I. C. Galera, "Assessment of the water quality of Mamba River of Mts. Palaypalay/Mataas na Gulod, Southern Luzon, Philippines," International Conference on Chemistry and Chemical Process, vol. 10, pp. 189-194, 2011.

[22] M. R. C. Enguito, V. E. Matunog, J. J. O. Bala, and Y. L. Villantes, "Water quality assessment of Carangan Estero in Ozamiz city, Philippines," Journal of Multidisciplinary Studies, vol. 1, no. 1, pp. 19-44, 2013.

[23] M. Thirupathaiah, C. H. Samatha, and C. Sammaiah, "Analysis of water quality using physico-chemical parameters in lower Manair reservoir of Karimnagar district, Andhra Pradesh," International Journal of Environmental Sciences, vol. 3, no. 1, p. 172, 2012.

[24] World Health Organization (WHO). (2013). International Standards for Drinking Water. [Online]. Available: http://apps.who.int/iris/bitstream/handle/10665/43845/a91160.pdf;jse ssionid=831EF957CB56620E996D5D9C6A4649FA? sequence $=1$

[25] E. O. Igbinosa and A. I. Okoh, "Impact of discharge wastewater effluents on the physico-chemical qualities of a receiving watershed in 
a typical rural community," International Journal of Environmental Science and Technology, vol. 6, no. 2, pp. 175-182, 2009.

[26] DENR Administrative Order No. 2016-08. (2016). Water Quality Guidelines and General Effluent Standards of 2016. [Online]. Available:

https://pab.emb.gov.ph/wp-content/uploads/2017/07/DAO-2016-08WQG-and-GES.pdf

[27] Water Quality Standards. [Online]. Available: http://mrccc.org.au/wpcontent/uploads /2013/10/Water-Quality-Salinity-Standards.pdf

[28] S. Higgins. (2019). Calcium: Why it Matters in Freshwater-and the Risks of Low Levels. [Online]. Available: https://www.iisd.org/ela/blog/commentary/calcium-matters-fresh-wate r-happens-not-enough/

Copyright $(\odot 2021$ by the authors. This is an open access article distributed under the Creative Commons Attribution License which permits unrestricted use, distribution, and reproduction in any medium, provided the original work is properly cited ( $\underline{\text { C BY 4.0) }}$.

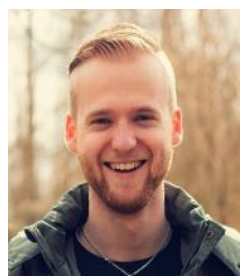

Bartimeues Nathan Wiederhold was previously affiliated at Van Hall Larenstein, University of Applied Sciences, Netherlands. He is currently a project engineer at Civil Engineering Company Van Gelder Groep. He finished his bachelor's degree at Van Hall Larenstein, University of Applied Sciences, Netherlands. As a land-and-water manager, his research interests focused on civil engineering and infrastructure. His previous researches are based on several water, soil, infrastructure, city planning, civil structures and many others.

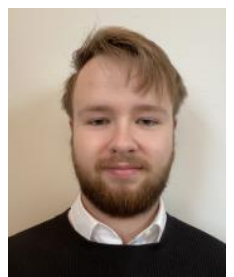

Tom Lichtenberg was previously affiliated at Van Hall Larenstein, University of Applied Sciences, Netherlands. He is currently affiliated at Wageningen University and Research where he is doing his master's degree in spatial planning. He has recently finished his bachelor's degree in land and water management at Van Hall Larenstein, University of Applied Sciences, in the Netherlands. Some of his research interests are, but not limited to are water quality, water quantity, adaptation to climate change and the quality of life as an aspect of urban planning. Tom's final thesis of his bachelor's focused on exploring options towards mitigating the drought in the agricultural landscape in the east of the Netherlands.

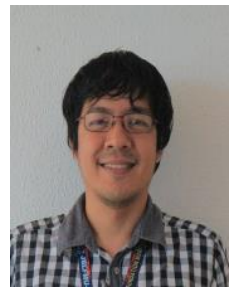

Roderick R. Germo, Ph.D. is currently a Faculty, member of the Unit Research Committee, and Statistician of John B. Lacson Foundation Maritime University (Arevalo), Inc. at Sto. Nino Sur, Arevalo, Iloilo City, Philippines. He finished his Master's degree in Engineering Education at the Western Institute of Technology (WIT) and his doctorate degree in Maritime Education at John B. Lacson Foundation Maritime University (Arevalo) Inc. He was just confirmed as Associate Member of the National Research Council of the Philippines (NRCP). His research interests focused on mathematics, maritime education, engineering and social sciences.

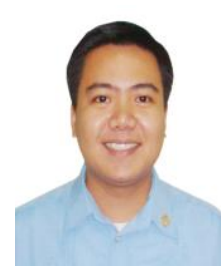

Brian Gil S. Sarinas is currently the research coordinator of John B. Lacson Foundation Maritime University (Arevalo), Inc. at Sto. Nino Sur, Arevalo, Iloilo City, Philippines. He finished his master's degree at the University of the Philippines Visayas (UPV) and his Ph.D. degree at West Visayas State University (WVSU). He is a member of DOST-NRCP (Department of Science and Technology-National Research Council of the Philippines) as regular member and National Organization of Science Teachers and Educators (NOSTE) as lifetime member. As a biology major, his research interests focused on biology education and fungi. His previous researches focused on wastewater effluents from inter-island vessels, heavy metals in the marine environment, rust removal, Thraustochytrid in Bunker C oil, phytoplankton in ballast water, ballast water management, Batiano River sediment analysis, coastal resources management, community structure of bivalves and gastropods, and other biology-chemistry maritime-related researches. 